\title{
INTRODUCTION
}

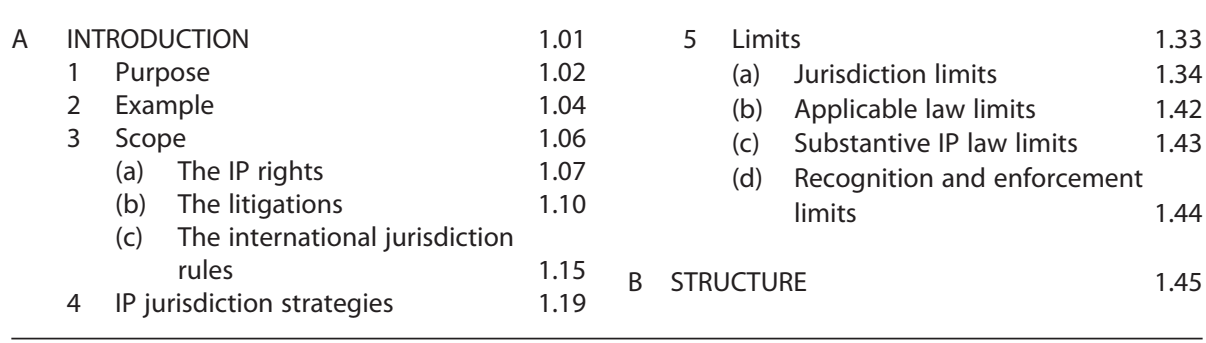

\section{A. INTRODUCTION}

This volume deals with intellectual property (hereinafter IP) jurisdiction 1.01 strategies. For the purpose of the study the term 'IP jurisdiction strategies' is defined as the advantages for the plaintiff to litigate based on a national IP right compared to litigating based on a corresponding European unitary IP right as further defined in section 4 below.

\section{Purpose}

The purpose behind the study is twofold. One purpose is that the approach whereas the international jurisdiction rules, ${ }^{1}$ which apply to a national IP right are compared vis-à-vis the international jurisdiction rules, which apply to a corresponding European unitary IP right - has not yet been taken in legal literature and is therefore new ${ }^{2}$ and that the study addresses, inter alia, new

1 The terms 'jurisdiction rules' and 'forum rules' are used synonymously for the purpose of the study.

2 This is not to say that the jurisdiction rules have not been subject to an examination in the legal literature see, inter alia, Joseph Drexl and Annette Kur (eds), Intellectual Property and Private International Law, Heading for the Future, IIC Studies, vol. 24, Hart Publishing, 2005; James J. Fawcett and Paul Torremans, Intellectual Property and Private International Law, second edn, Oxford Private International Law Series, 2011; Conflict of Laws in Intellectual Property, The CLIP Principles and Commentary, European Max Planck Group on Conflicts of Laws in Intellectual Property, Oxford University Press, 2013; Stefan Leible and Ansgar Ohly (eds), Intellectual Property and Private International Law, Mohr Siebeck, 2009; Arnaud Nuyts (ed.), International Litigation in Intellectual Property and Information Technology, Kluwer Law International, 2008; Marta Pertegás Sender, Cross-Border Enforcement of Patent Rights, Oxford Private International Law Series, 2002; Eike Scharper, Durchsetzung der Gemeinschaftsmarke, Internationale Zuständigkeit, anwendbares Recht und Rechtsfolgen bei Verletzung, Carl Heymanns Verlag, 2006; Benedetta Ubertazzi, Exclusive Jurisdiction 
forum rules ${ }^{3}$ and new decisions. ${ }^{4}$ Another purpose is that the study provides practitioners with a platform that enables them to decide whether to litigate based on a national IP right rather than on a corresponding European unitary IP right, which in turn is valuable knowledge in cross-border IP litigation cf. section 4.

1.03 For illustration purposes an example is given in section 2. In section 3 the scope of the study is addressed and in section 4 the term 'IP jurisdiction strategies' is defined. In section 5 the limits of the study are laid down and finally in section B the structure of the study is outlined.

\section{Example}

1.04 The example below may illustrate the subject of the present study. The example is referred to throughout the study. The example reads as follows:

Frogs $\mathrm{GmbH}$ is a shoe manufacturer based in Munich, Germany. Frogs GmbH markets and sells a foam shoe throughout the EU under the name Frogs. Frogs $\mathrm{GmbH}$ owns a number of IP rights:

First, the shoe name Frogs is trademark protected at national levels in the Member States and at EU level as a European union trademark right (EUTM).

Secondly, the look of the shoe is design protected at national levels in the Member States and at EU level as a registered and unregistered Community design right (CD).

Thirdly, the technical impact of the shoe sole is patent protected at national levels in the Member States and as a unitary patent right (UP).

Fourthly, Frogs GmbH has established a research and development (R\&D) department, which is being funded by the income of an attractive plant variety right owned by Frogs $\mathrm{GmbH}$. The plant variety is protected on national levels in the Member States and on EU level as a Community plant variety right (CPV).

A situation has now come up where a farmer from Sicily has copied Frogs GmbH's business model and has started a company under the name Frox SpA. The company

in Intellectual Property, Max Planck Institut für Ausländisches und Internationales Privatrecht, Mohr Siebeck, 2012 and Toshiyuki Kono, Intellectual Property and Private International Law, Comparative Perspectives, Hart Publishing, 2012.

3 Art. 33 AUPC.

4 Case C-523/10, Wintersteiger AG v Products $4 U$ Sondermaschinenbau GmbH; Case C-133/11, Folien Fischer $A G$, Fofitec AG v Ritrama SpA; Case C-170/12, Peter Pinckney v KDG Mediatech AG; Case C-387/12, Hi Hotel HCF SARL v Uwe Spoering; Case C-360/12, Coty Prestige Lancaster Group GmbH v First Note Perfumes NV; Case C-441/13, Pez Hejduk v EnergieAgentur NRW GmbH; Case C-25/16, Nintendo Co. Ltd. v BigBen Interactive GmbH, BigBen Interactive SA (pending); Case C-230/15, Brite Strike Technologies Inc. v Brite Strike Technologies SA; Case C-433/16, Bayerische Motoren Werke AG v Acacia S.r.l. (pending); Case C-618/15, Concurrence SARL v Samsung Electronics France SAS and Amazon Services Europe Sàrl; and case C-617/15, Hummel Holding $A / S v$ Nike Inc. and Nike Retail BV (pending). 
has its statutory seat in Palermo, Italy whereas its management and control centre is located in Amsterdam, the Netherlands and its principal place of business is in Paris, France. Frox SpA also has an establishment in London, UK. Furthermore Frox SpA has an independent legal entity in Copenhagen, Denmark (Frox ApS) and another independent legal entity in Stockholm, Sweden (Frox AB).

Frox $\mathrm{SpA}$ is - in line with Frogs $\mathrm{GmbH}$ - funded by the income of a plant variety marketed and sold throughout the EU. The plant variety is similar to the one owned by Frogs GmbH. Frox SpA markets and sells thousands of 1:1 counterfeited foam shoes in Italy, Spain, France and Austria under the name Frox. The shoes are manufactured in Italy. The plant variety and the shoes are distributed from both Italy and the UK. The shoes are advertised for on frox.com.

Frogs $\mathrm{GmbH}$ has become aware of the infringements of their trademark, design, patent and plant variety rights and has sent Frox SpA a cease and desist $(C \& D)$ letter, however, with no effect. Frogs $\mathrm{GmbH}$ intends to enforce their IP rights but has two overall concerns:

The first concern relates to the advantages from a jurisdictional viewpoint for Frogs $\mathrm{GmbH}$ to litigate on the basis of their national IP rights compared to doing so on the basis of their corresponding European unitary IP right. ${ }^{5}$

The second concern relates to the advantages from a jurisdictional viewpoint for their counterpart, Frox SpA, to litigate on the basis of Frogs $\mathrm{GmbH}$ 's national IP rights compared to doing so on the basis of Frogs GmbH's corresponding European unitary IP right. 6

The strategic jurisdictional reflections raised in the above example have most likely also been done in the series of ongoing lawsuits between Samsung and Apple. ${ }^{7}$ Here Samsung brought, inter alia, an action for a declaration of non-infringement ${ }^{8}$ also known as a negative declaration ${ }^{9}$ or just a declaratory

5 A non-exhaustive list of factors determining the jurisdictional advantages for the plaintiff is provided for in section 4.

6 Ibid.

7 Infra note 11.

8 The term 'action for declaration of non-infringement' is used, inter alia, in arts 96(b) EUTMR, 81(b) CDR and 32(1)(b) AUPC and by legal scholars, inter alia, Sender, supra note 2, 81.

9 The term 'negative declaration' is used by the CJEU in case C-133/11, Folien Fischer $A G$, n. 4, para. 56 and by legal scholars, inter alia, Fawcett and Torremans, supra note 2, 5.37; Ulrich Magnus and Peter Mankowski, Brussels I Regulation European Commentaries on Private International Law, 2nd revised edn, 2012, 229; Anna Gardella, 'Torpedoes and Actions for Negative Declarations in International IP Law Litigation' in Arnaud Nuyts (ed.), International Litigation in Intellectual Property and Information Technology, Kluwer Law International, 2008, p. 181; and Ulf Maunsbach, 'Jurisdiction in Relation to Online Cross-Border Infringements: The Code and the Law' in Dan Jerker B. Svantesson and Stanley Greenstein (eds), Internationalisation of Law in the Digital Information Society, 2013, p. 182. 
action ${ }^{10}$ against Apple in the UK ${ }^{11}$ claiming that Samsung's Galaxy tablets did not infringe Apple's registered CD. ${ }^{12}$ The reason for doing so could be that it would be advantageous to Samsung since the action could be brought at their own domicile in the $\mathrm{UK}^{13}$ and since the UK courts would have unrestricted jurisdiction. ${ }^{14}$ The strategy appeared successful since Samsung's Galaxy tablets were found not to infringe Apples registered CD. ${ }^{15}$

\section{Scope}

1.06 The scope of the study is defined by three factors. The first factor is the IP rights covered by the study (section a); the second factor is the litigations covered by the study (section b) and the third factor is the international jurisdiction rules covered by the study (section c).

\section{(a) The IP rights}

1.07 The IP rights covered by the study include trademark, design, plant variety and patent rights. The choice of those four kinds of IP rights has been predefined given that European unitary IP rights only exist within these areas. ${ }^{16}$

1.08 Thus, the position for a national trademark right is compared with the position for the corresponding EUTM having a unitary character ${ }^{17}$ the position for a national design right is compared with the position for the corresponding $\mathrm{CD}$ having a unitary character ${ }^{18}$ the position for a national plant variety right is compared with the position for the CPV having a unitary

10 The term 'declaratory action' is used, inter alia, in the CLIP Principles and Commentary, supra note 2, 173 (2:602.C01).

11 High Court of Justice, Chancery Division Patents Court, Samsung Electronic (UK) Ltd. v Apple Inc., case no HC 11 C 03050, 9 July 2012.

12 Community Design No. 000181607-0001 of 24 May 2004. For the purposes of the present study it is explicitly noted that Apple Inc. did not have any corresponding national design right in, inter alia, the UK.

13 The question of jurisdiction is not mentioned in the judgment. Given, however, that non-infringement actions cannot be brought at forum delicti making art. 82(5) CDR inapplicable the action must have been brought either at Apple Inc's establishment in the UK following art. 82(1) CDR or at Samsung Electronics (UK) Ltd's domicile in the UK following art. 82(2) CDR. Either one equals Samsung Electronics (UK) Limited's home domicile.

14 Art. 83(1) CDR. The distinction between unrestricted and restricted jurisdiction is addressed in section 4 (factor 4).

15 Samsung Electronic (UK) Ltd. v Apple Inc., n. 11, para. 191.

16 Two modifications apply i.e. that a UP is not yet obtainable cf. art. 18(2) UPR and that a protected designation of origin right (PDO), a protected geographical indication right (PGI) and a speciality guaranteed right (SPG) are also found in European unitary versions but are excluded from the scope of the study since they are all subject to the same jurisdiction rules, which apply to national IP rights cf. s. 5(a).

17 Art. 1(2) EUTMR.

18 Art. 1(3) CDR. 
character ${ }^{19}$ and the position for a national patent right is compared with the position for the UP having a unitary character, ${ }^{20}$ which contrary to the above does not set in automatically but is granted upon request by the applicant. ${ }^{21}$

For the purpose of the present study it is clarified that $\mathrm{CPV}$ protection cannot be combined with national plant variety protection, ${ }^{22}$ which is available in almost every EU Member $\operatorname{State}^{23}$ and that therefore the jurisdictional advantages of litigating based on a national plant variety right rather than litigating based on the CPV must be determined at registration level and not, as the remaining IP rights covered by the study, on infringement level; that the IP rights covered count also unregistered versions on both national ${ }^{24}$ and $\mathrm{EU}$ levels; ${ }^{25}$ that a national IP right is covered regardless of whether it has been applied for centrally ${ }^{26}$ or on a Member State-by-Member State basis and that a European unitary IP right is covered regardless of whether it extends to every $28 \mathrm{EU}$ Member States (such as the EUTM, CD and CPV)27 or only to 26 EU Member States (such as the UP). ${ }^{28}$

\section{(b) The litigations}

The litigations covered by the study count infringement actions where invalidity is not raised, non-infringement action ${ }^{29}$ where invalidity is not raised and finally infringement and non-infringement actions where invalidity is raised.

19 Art. 2 CPVR.

20 Arts 2(c) cf. 3(2) UPR and art. 2(f) AUPC.

21 Art. 9 cf. recital 5 UPR.

22 Art. 3 cf. 92(1) CPVR.

23 Members of the International Union for the Protection of New Varieties of Plant of 1961 as revised in Geneva in 1972, 1978 and 1991 number every Member State except Cyprus, Greece, Luxembourg and Malta cf. upov.int/members.

24 An example of an unregistered IP right at national level could be a Danish trademark acquired through use cf. §3(1)(2) Danish Trademarks Act.

25 An example of an unregistered IP right at EU level could be the unregistered CD cf. art. $11 \mathrm{CDR}$.

26 A central application procedure is available for trademarks cf. Madrid System for the International Registration of Marks and the Protocol Relating to the Madrid Agreement Concerning the International Registration of Marks, adopted at Madrid on June 27, 1989; for patents cf. Convention on the Grant of European Patents of 5 October 1973 as revised by the Act revising art. 63 EPC of 17 December 1991 and the Act revising the EPC of 29 November 2000 and Patent Corporation Treaty done at Washington on June 19, 1970 as amended on September 28, 1979 as modified on February 3, 1984 and on October 3, 2001 and for designs cf. Hague Agreement concerning the International Registration of Industrial Designs.

27 The EUTM, CD and CPV extend also to Croatia being a new Member State as from 1 July 2013 cf. Treaty concerning the Accession of the Republic of Croatia, Council of the European Union, Brussels of 7 November 2011 14409/11 cf. Communication no. 4/12 of the President of OHIM of 12 December 2012 concerning the Enlargement of the European Union to Croatia and Press Release of 1 July 2013 of CPVO concerning the Enlargement of the European Union to Croatia.

28 The UP extends only to 26 Member States since Croatia and Spain are not parties to the UPR.

29 The term 'non-infringement action' is synonymous to the terms 'action for declaration of non-infringement', 'negative declaration' and 'declaratory action'. 
1.11 The choice of those three kinds of actions has also been predefined given that they express the claims, namely infringement, non-infringement and invalidity, which may be raised between the rightholder (being the party claiming IP protection) and the infringer (being the party allegedly infringing the IP right). For the purpose of the present study, therefore, the actions relate to IP rights, which have allegedly been infringed. For reasons of clarity the actions are dealt with separately below. ${ }^{30}$

1.12 Infringement actions are the first kind. In these actions, which also include threatened infringements, the rightholder claims infringement of his/her trademark, design, plant variety or patent right. As a defence the infringer claims non-infringement of the IP right e.g. since the use of the mark/sign creates no risk of confusion, ${ }^{31}$ since the use of the design produces a different overall impression on the informed user, ${ }^{32}$ since the use of the plant variety is subject to the farmers privilege ${ }^{33}$ or since the use of the technique is outside the scope of the patent claims. ${ }^{34}$ In infringement actions the initiative lies with the rightholder being the one choosing the forum.

Applying the example in section 2 Frogs $\mathrm{GmbH}$ may bring an infringement action against Frox SpA. During the action Frogs GmbH claims infringement of their IP rights and as a defence Frox SpA claims non-infringement e.g. since the sign Frox is not confusingly similar to the trademark Frogs; since their design imposes an overall different impression on the informed user compared to Frogs' design and/or since their shoe sole is based on a different technique outside the scope of Frogs' patent claim.

1.13 Non-infringement actions are the second kind. In these actions the infringer acts as the plaintiff and the rightholder acts as the defendant and so the parties trade places. The idea of bringing any such action is not to impose any liability on the rightholder. Rather the idea is to rule out the infringer's own liability by seeking a finding that his/her conduct does not infringe the rightholder's trademark, design, plant variety or patent right. ${ }^{35}$ As a defence the rightholder claims infringement of his/her IP right. In non-infringement actions the initiative lies with the infringer being the one choosing the forum.

30 The claims raised in the below actions can be (and are often) combined in various ways e.g. may the infringer claim invalidity and in the alternative non-infringement.

31 Art. 5(1)(b) TMD and art. 9(1)(b) EUTMR.

32 Art. 9(1) DD and art. 10(1) CDR.

33 For national plant variety rights the substantial law has not been harmonized at EU-level cf. therefore the Member States own plant variety acts. For the CPV cf. art. 14 CPVR.

34 For national patent rights the substantial law has not been harmonized at EU-level cf. therefore the Member States own patent acts. For the UP cf. arts 7 UPR cf. 24(c) AUPC cf. 69 EPC.

35 Opinion of Advocate General Jääskinen in case C-133/11, Folien Fischer AG, n. 4, para. 47 and judgment of the CJEU, para. 42. 
Applying the example in section 2 Frox SpA may bring a non-infringement action against Frogs $\mathrm{GmbH}$ seeking a finding, inter alia, that the marketing and selling of their shoes under the name Frox in Italy, Spain, France and Austria does not infringe Frogs GmbH's trademark, design and patent rights e.g. since the sign Frox is not confusingly similar to the trademark Frogs; since their design imposes an overall different impression on the informed user compared to Frogs' design and/or since their shoe sole is based on a different technique outside the scope of Frogs' patent claim. As a defence Frogs $\mathrm{GmbH}$ claims infringement.

Invalidity actions are the third kind. Invalidity may be raised in various ways i.e. as a claim in infringement actions; as a counterclaim/(defence) in infringement actions; as a claim in non-infringement actions and as a counterclaim/ (defence) in non-infringement actions. ${ }^{36}$ In trademark cases invalidity can be raised e.g. if the trademark lacks distinctiveness; 37 if the trademark has not been used for five years ${ }^{38}$ or if the trademark has become the common name of the product or service in respect of which it is registered. ${ }^{39}$ In design cases invalidity can be raised e.g. if the design lacks novelty or individual character. ${ }^{40}$ In plant variety cases invalidity can be raised e.g. if the variety lacks novelty. ${ }^{41}$ Finally, in patent cases invalidity can be raised e.g. if the invention lacks novelty or inventive step. ${ }^{42}$ In invalidity actions the initiative is either split between the parties (e.g. where the rightholder chooses the forum and the infringer claims invalidity) or lies fully with one of the parties (e.g. where the infringer chooses the forum and claims invalidity).

Applying the example in section 2 Frogs $\mathrm{GmbH}$ may bring an infringement action against Frox SpA. During the action Frogs $\mathrm{GmbH}$ claims infringement of their IP rights and as a defence Frox SpA claims invalidity by way of a counterclaim/(defence) since the $\mathrm{CD}$ has not been subject to any substantial law examination and if it had the design would show the lack of novelty and individual character because the design is known from wooden clogs and/or since the technique of the shoe sole lacks inventive step since it is obvious to a person skilled in the art. Alternatively, Frox SpA may bring a non-infringement action against Frogs $\mathrm{GmbH}$ claiming invalidity of Frogs GmbH's IP rights by way of a claim and as a defence Frogs $\mathrm{GmbH}$ claims infringement since the sign Frox is confusingly similar to the trademark Frogs; since the shoes imposes an overall similar impression on the informed user compared to Frogs' design and/or since the shoe sole is based on the same technique within the scope of Frogs' patent claim.

36 See below for examples.

37 Arts 3(1)(a) TMD and 7(1)(b) EUTMR.

38 Arts 16(1) TMD and 51(1)(a) EUTMR.

39 Arts 20(1)(a) TMD and 51(1)(b) EUTMR.

40 Arts 11(1)(b) cf. 4-5 DD and arts 25(1)(b) cf. 5-6 CDR.

41 For national plant variety rights the substantial law has not been harmonized at EU-level cf. therefore the Member States own plant variety acts. For the CPVR cf. art. 20(1)(a) cf. 10 CPVR.

42 For national patent rights the substantial law has not been harmonized at EU-level cf. therefore the Member States own patent acts. For the UP cf. arts 7 UPR cf. 24(c) AUPC cf. 54 and 56 EPC. 


\section{(c) The international jurisdiction rules}

1.15 The international jurisdiction rules covered by the study count the defendant's domicile, ${ }^{43}$ establishment, ${ }^{44}$ multiple defendants' ${ }^{45}$ forum delicti ${ }^{46}$ and exclusive jurisdiction ${ }^{47}$ rules which, with variations, all apply to both a national IP right and to every European unitary IP right; the plaintiff's domicile rule, which applies to the EUTM, CD and $\mathrm{CPV}^{48}$ and likely in a camouflaged version to the UP ${ }^{49}$ and finally the central division rule, which applies to the UP. ${ }^{50}$ In addition to the above 'fall back' rules may apply under the EUTM, $\mathrm{CD}$ and CPV cf. Chapter 2. For the purpose of the study focus lies with the following two areas:

1.16 The first focus area is the number of international jurisdiction rules available to the plaintiff. The reason that the number of international jurisdiction rules is a focus area is that the jurisdiction framework is very complex given that a variety of factors decide what rules apply, inter alia, the territorial extent of the IP right (whether national or European unitary); the character of the national IP right (whether registered or unregistered); the character of the European unitary IP right (whether a trademark, design, plant variety or patent right with different rules remaining applicable in the background); the action (whether infringement, non-infringement or invalidity) and on the domicile of the defendant (whether in the EU, in the EFTA or outside the EU/EFTA). The number of international jurisdiction rules available to the plaintiff is addressed in Chapters 2-3.

1.17 The second focus area is the nature of the international jurisdiction rules available to the plaintiff. Any such count in the ones mentioned above. Not every international jurisdiction rule is in focus e.g. is the exclusive jurisdiction rule $^{51}$ not in focus given that it has recently been subject to a thorough study ${ }^{52}$ and the same goes for the central division rule ${ }^{53}$ given its limited application. Rather focus lies with, but is not limited to, forum delicti. The reason is that in IP litigation forum delicti is the real alternative to the defendant's domicile in

43 Arts 4 BR, 97(1) EUTMR, 82(1) CDR, 101(2)(a) CPVR and 33(1)(b) AUPC cf. Chapter 5.

44 Arts 7(5) BR, 97(1) EUTMR, 82(1) CDR, 101(2)(a) CPVR and 33(1)(b) AUPC cf. Chapter 6.

45 Arts 8(1) BR, 94(2)(a) EUTMR, 79(3)(a) CDR, 101(1) CPVR and 33(1)(b) AUPC cf. Chapter 8.

46 Arts 7(2) BR, 97(5) EUTMR, 82(5) CDR, 101(3) CPVR and 33(1)(a) AUPC cf. Chapter 9.

47 Arts 24(4) BR, 96(d) and 99(2) cf. 56 EUTMR, 81(d) and 84(4) cf. 52 CDR, 20 CPVR and 33(3) and (4) AUPC cf. Chapter 11.

48 Arts 97(2) EUTMR, 82(2) CDR and 101(2)(b) CPVR cf. Chapter 7.

49 Arts 33(1)(a) cf. 34 AUPC cf. Chapter 7.

50 Art. 33(1), (2), (3) and (4) AUPC cf. Chapter 10.

51 Chapter 11.

52 Ubertazzi, supra note 2.

53 Chapter 10. 
situations where there is only one defendant ${ }^{54}$ and that the CJEU has recently handed down a number of decisions, which to some extent clarify the scope and impact of forum delicti to both national IP rights ${ }^{55}$ and to European unitary IP rights. ${ }^{56}$ The forum delicti rule is addressed in Chapter 9.

In sum, the IP rights, the litigations and the international jurisdiction rules covered by the study can be illustrated as in Table 1.1 below.

Table 1.1 Scope of the study

\begin{tabular}{|c|c|c|}
\hline & $\begin{array}{c}\text { SITUATION } 1 \\
\text { (National IP rights) }\end{array}$ & $\begin{array}{c}\text { SITUATION } 2 \\
\text { (European unitary IP rights) }\end{array}$ \\
\hline IP rights & $\begin{array}{l}\text { - National trademark rights } \\
\text { - National design rights } \\
\text { - National plant variety rights } \\
\text { - National patent rights }\end{array}$ & $\begin{array}{l}\text { - European union trademark (EUTM) } \\
\text { - Community design (CD) } \\
\text { - Community plant variety (CPV) } \\
\text { - Unitary patent (UP) }\end{array}$ \\
\hline Litigations & $\begin{array}{l}\text { - Infringement actions } \\
\text { - Non-infringement actions } \\
\text { - Invalidity actions }\end{array}$ & $\begin{array}{l}\text { - Infringement actions } \\
\text { - Non-infringement actions } \\
\text { - Invalidity actions }\end{array}$ \\
\hline $\begin{array}{l}\text { International } \\
\text { jurisdiction rules }\end{array}$ & $\begin{array}{l}\text { - The defendant's domicile rule } \\
\text { - The establishment rule } \\
\text { - The multiple defendants' rule } \\
\text { - The forum deliciti rule } \\
\text { - The exclusive jurisdiction rule }\end{array}$ & $\begin{array}{l}\text { - The defendant's domicile rule } \\
\text { - The establishment rule } \\
\text { - The multiple defendants' rule } \\
\text { - The forum delicti rule } \\
\text { - The exclusive jurisdiction rule } \\
\text { - The plaintiff's domicile rule (EUTM, CD, CPV, } \\
\text { (UP)) } \\
\text { - The central division rule (UP) }\end{array}$ \\
\hline
\end{tabular}

\section{IP jurisdiction strategies}

In IP litigation a number of strategic decisions must be made by the plaintiff whether acting as the rightholder or as the infringer ${ }^{57}$ - prior to bringing the action against the defendant in a given Member State. Such decisions have one thing in common: to bring the action where it is most advantageous for the plaintiff. To determine what is most advantageous for the plaintiff, a large number of issues must be addressed. Some have a procedural law nature, ${ }^{58}$

54 Christian Heinze, Jurisdiction under the CLIP Principles available at http://www.tomeika.jur.kyushu-u. ac.jp/chizai/symposium/paper/004_08May09_Heinze.pdf p. 8 .

55 Case C-523/10, Wintersteiger, n. 4; case C-133/11, Folien Fischer; case C-170/12, Peter Pinckney; case C-387/12, Hi Hotel; case C-441/13, Pez Hejduk; case C-230/15, Brite Strike and case C-618/15, Concurrence SARL.

56 Case C-360/12, Coty Prestige, n. 4; case C-25/16, Nintendo Co. Ltd., n. 4; case C-433/16, Bayerische Motoren Werke $A$ Gand case C-617/15, Hummel Holding $A / S$ v Nike Inc. and Nike Retail BV (pending).

57 Section 3(b).

58 The procedural law issues include, inter alia, the rules on examination of witnesses; the rules on expert evidence; the rules on disclosure of documents; the rules on obtaining and preservation of evidence; the rules on search and seizure; the rules on possible suspensive effect of decisions and the rules on legal costs. Any such rules are subject to the laws of the Member State where the case is being litigated, the so-called lex fori, regardless of whether the IP right in question is a national IP right or a European unitary IP right cf. arts 
some have a substantial IP law nature, ${ }^{59}$ some have a penal law nature, ${ }^{60}$ some have a non-law nature ${ }^{61}$ and some have a private international law nature. The study does not deal with the former four i.e. the procedural law, substantive IP law, penal law and non-law issues. Rather the study deals with the latter i.e. the private international law issues.

1.20 For the purpose of the study such issues are defined as the jurisdictional advantages for the plaintiff to litigate based on a national IP right compared to litigating based on a corresponding European unitary IP right. ${ }^{62}$

1.21 Crucial, therefore, is what can be considered a jurisdictional advantage for the plaintiff in IP litigation. For that purpose, a non-exhaustive list of factors can be identified. The factors - where some are general because they apply irrespectively of whether the plaintiff acts as the rightholder or as the infringer ${ }^{63}$ and others are specific because they depend on whether the plaintiff acts as the rightholder or as the infringer ${ }^{64}$ - can be divided into overall two groups (A and B). 65

1.22 Group A, which is also factor 1 , relates to the number of international jurisdiction rules available to the plaintiff (Chapters 2-3). More jurisdiction rules is an advantage for the plaintiff since they leave him/her a discretion on where to sue, which in turn may limit his/her risks. The concept is known as forum shopping (Chapter 4 section C.3).

101(3) EUTMR, 88(3) CDR and 103 CPVR with the sole exception of the UP, which has its own procedural laws cf. Rules of Procedure of the Unified Patent Court of 19 October 2015. The above elements are included in the critique of Wintersteiger cf. Chapter 9 section B.1(a)(ii), Principle 3: Avoiding forum shopping.

59 The substantial IP law issues include, inter alia, the scope of protection for national patent or plant variety rights where the rules have not been harmonized at EU level.

60 The penal law issues include, inter alia, the damages awarded by the courts. Any such damages vary widely among the Member States.

61 The non-law issues include, inter alia, considerations in terms of not harming the brand of the plaintiff and/or harming the brand of the defendant.

62 Section 1.

63 Factors 1-4.

64 Factors 5-9.

65 Factors 1-9 are defined in terms of what is usually considered an advantage for the plaintiff. The risk of doing so is that the details fade. For example where in factor 6 joint adjudication is listed as an advantage for the plaintiff acting as the rightholder this does not preclude that split adjudication may sometimes be an advantage for him/her. This would typically be the case where the rightholder has a weak IP right. In that case he/she may take an interest in having the validity of the IP right tried in a number of Member States in the hope that one of these Member States will declare the IP right valid which, in turn, can be used by the rightholder to have the infringer stop marketing a product in the EU cf. Fawcett and Torremans, supra note $2,7.32$ with references. 
Group B relates to the nature of the international jurisdiction rules available to 1.23 the plaintiff (Chapters 4-11) and covers the following factors, which are counted consecutively from the one above.

Factor 2, therefore, is whether a jurisdiction rule allows for more available fora (Chapters 5, 6 and 9). The factor differs from the one above since it addresses available fora within one same jurisdiction rule. The advantages above apply mutatis mutandis unless only one party benefits in which event it may only be an advantage for the plaintiff acting as the rightholder or as the infringer.

Factor 3 is whether the action can be brought in the plaintiff's home Member

State. This is possible, inter alia, if a plaintiff's domicile rule is available (Chapter 7) or if the infringement occurred there (Chapter 9 section C.4). The advantage of bringing the action in the plaintiff's home Member State are, inter alia, that the plaintiff saves time and costs for travelling and for foreign external counsels provided that any such are hired along with national external counsels; ${ }^{66}$ that the plaintiff saves time and costs for translation of written submissions and translation of the oral procedure given that the proceedings are conducted in the plaintiff's own mother tongue ${ }^{67}$ and that the plaintiff may feel more confident given that the case is conducted on the basis of his/her own procedural laws.

Factor 4 is the extent of jurisdiction. The extent of jurisdiction can either be unrestricted or restricted. Unrestricted jurisdiction also known as, inter alia, extraterritorial jurisdiction, ${ }^{68}$ cross-border jurisdiction, ${ }^{69}$ global jurisdiction, ${ }^{70}$ general jurisdiction ${ }^{71}$ or central jurisdiction ${ }^{72}$ allows a competent court to hear

66 If, applying the example in section 2, Frox SpA brings a non-infringement action against Frogs $\mathrm{GmbH}$ in Italy following art. 7(2) Brussels I Regulation as interpreted in Folien Fischer cf. Chapter 9 Frox SpA will most likely hire their local Italian legal counsels contrary to the situation where any such action is brought in Germany following art. 4 Brussels I Regulation where Frox SpA will most likely hire both foreign German legal counsels along with their own Italian legal counsels.

67 If, applying the example in section 2, Frox SpA brings a non-infringement action against Frogs $\mathrm{GmbH}$ in Italy following art. 7(2) Brussels I Regulation as interpreted in Folien Fischer cf. Chapter 9 the action will be conducted in Italian on the basis of Italian procedural laws being lex fori and Frox SpA will save time and costs for translation of the written submissions and the oral proceedings into German.

68 Alexander Peukert, 'Territoriality and Extraterritoriality in Intellectual Property Law', in Gunther Handl and Joachim Zekoll (eds), Beyond Territoriality: Transnational Legal Authority in an Age of Globalization, Queen Mary Studies in International Law, Brill Academic Publishing, Leiden/Boston, 2011; and Graeme Dinwoodie, 'Developing a Private International Intellectual Property Law: The Demise of Territoriality' (2009) 51 William and Mary Law Review 711.

69 Sender, supra note 2, 3.115 et seq.

70 Magnus and Mankowski, supra note 9, 246.

71 Conflict of Laws in Intellectual Property, The CLIP Principles and Commentary, supra note 2, 56 (2:101.C01) and 85 (2:203.C03) and Kono, supra note 2, 23.

72 Annette Kur, 'Case C-235/09, DHL Express v. Chronopost, Judgment of the Court of Justice (Grand Chamber) of 12 April 2011' (2012) 49(2) Common Market Law Review 753-66, 753 note 2. 
a claim for infringement irrespectively of where the infringement occurred ${ }^{73}$ (hereinafter unlimited full jurisdiction $)^{74}$ whereas restricted jurisdiction also known as territorial jurisdiction 75 or country-by-country jurisdiction only allows a competent court to hear a claim for infringement, which occurred in the Member State where the court is located ${ }^{76}$ (hereinafter limited forum jurisdiction). ${ }^{77}$ The advantages of bringing the action in a forum having unlimited full jurisdiction is that it allows the case to be addressed in one operation, which in turn saves the plaintiff time and costs for later court cases (winner takes it all) whereas the advantages of bringing the action in a forum having limited forum jurisdiction is that it allows the plaintiff to bring a test case, which can later be used as a reference or as a means of pressure to have the defendant enter into a settlement. For the purpose of the present study discretion between unlimited full and limited forum jurisdiction is an advantage for the plaintiff. The extent of jurisdiction is addressed for every forum rule subject to the present study cf. Chapters 5-11.

1.27 Factor 5 is whether change of forum principles and rules apply. Any such principles and rules include, inter alia, whether a court may decline jurisdiction of its own discretion because it finds that another court is better suited to address the case (forum non-conveniens) ${ }^{78}$ or whether a defendant by so requesting may force a court (regional division) to refer the case to another court (central division). ${ }^{79}$ Any such change of forum principles and rules are an advantage for the plaintiff acting as the infringer since they allow the action to be prolonged.

73 See e.g. within the meaning of art. 7(2) Brussels I Regulation for infringement of personality rights case C-68/93, Fiona Shevill, Ixora Trading Inc., Chequepoint SARL and Chequepoint International Ltd. v Presse Alliance $S A$, para. 25.

74 Applying the example in section 2 Frogs $\mathrm{GmbH}$ may bring an infringement action against Frox SpA in Italy being the defendant's domicile cf. art. 4 Brussels I Regulation. The courts at any such place have unlimited full jurisdiction cf. Chapter 5 and are therefore competent, if Frogs $\mathrm{GmbH}$ so claims, to order Frox SpA to stop manufacturing the foam shoes in Italy, to stop distributing them through the branch office in London and to stop marketing and selling them in Italy, Spain, France and Austria, see also Conflict of Laws in Intellectual Property, The CLIP Principles and Commentary, supra note 2, 85 (2:203C03) and Fawcett and Torremans, supra note 2, 5.08.

75 Conflict of Laws in Intellectual Property, The CLIP Principles and Commentary, ibid.

76 See e.g. within the meaning of art. 7(2) Brussels I Regulation for infringement of personality rights case C-68/93, Fiona Shevill, para. 30.

77 Applying the example in section 2 Frogs may bring an infringement action against Frox SpA in Spain being a place where the IP right is registered cf. art. 7(2) Brussels I Regulation. The courts at any such place have limited forum jurisdiction cf. Chapter 9 and are therefore only competent, if Frogs $\mathrm{GmbH}$ so claims, to order Frox SpA to stop marketing and selling the foam shoes in Spain. The Spanish courts cannot order Frox SpA to stop manufacturing the foam shoes in Italy or order them to stop distributing them to, inter alia, France or Austria through the branch office in London, see also Conflict of Laws in Intellectual Property, The CLIP Principles and Commentary, supra note 2.85 (2:203C03) and Fawcett and Torremans, supra note 2, 5.08.

78 Annette Kur and Thomas Dreier, European Intellectual Property Law, Text, Cases and Materials, Edward Elgar Publishing, 2013, p. 489.

79 Art. 33(2)(second sentence) AUPC. 
Factor 6 is the interrelation between infringement and invalidity. The interrelation may take different forms, inter alia, that the same court of the same Member State is competent to address both infringement and invalidity; 80 that different courts of the same Member State are competent to address infringement and invalidity; ${ }^{81}$ that the courts of a Member State are competent to address infringement whereas a public authority in the same Member State is exclusively competent to address invalidity; ${ }^{82}$ that the courts of different Member States are competent to address infringement and invalidity ${ }^{83}$ or finally that the courts of a Member State are competent to address infringement whereas a public authority of another Member State is exclusively competent to address invalidity. ${ }^{84}$ For the purpose of the present study the former three (where infringement and invalidity are decided in the same Member State) are referred to as joint adjudication whereas the latter two (where infringement and invalidity are decided in different Member States) are referred to as split adjudication. If the plaintiff acts as the rightholder joint adjudication is (usually) an advantage since it speeds up the process, which in turn saves him/her time and $\operatorname{costs}^{85}$ whereas split adjudication is (usually) an advantage if the plaintiff acts as the infringer since the action will be prolonged. The interrelation between infringement and invalidity is addressed for every forum rule subject to the present study cf. Chapters 5-11.

Factor 7 is the interrelation between non-infringement and invalidity. The interrelation may take different forms namely that invalidity may be raised in

80 An example would be, inter alia, arts 96(a) and (d) EUTMR and 81(a) and (d) CDR cf. Fawcett and Torremans, supra note 2, 8.48 and 8.117 .

81 An example would be, inter alia, where a local or regional division is located within the same Contracting Member State as the central division within the meaning of art. 33(3)(b) AUPC.

82 An example would be, inter alia, where the courts of France are competent to address infringement of a CPV cf. art. 101(2)(c) CPVR whereas the CPVO located in France are exclusively competent to address invalidity cf. art. 20 CPVR.

83 An example would be, inter alia, where the defendant's domicile in art. 4 BR does not coincide with the place(s) of registration in art. 24(4) BR cf. case C-4/03, Gesellschaft für Antriebstechnik mbH \& Co. KG v Lamellen und Kupplungsbau Beteiligungs $K G$, para. 32.

84 An example would be, inter alia, where the defendant's domicile in art. 101(2)(a) CPVR does not coincide with the location of the CPVO.

85 Joint adjudication may, however, not always be an advantage for the plaintiff acting as the rightholder even though infringement and invalidity are addressed within the same Member State. The reason is that the infringement action risks being stayed pending the result of the invalidity action cf. art. 106(2) CPVR. The stay of procedure rules are, however, not addressed for the purpose of the present study cf. section 5(a) (limit 7). 
non-infringement actions, ${ }^{86}$ which may lead to either split $^{87}$ or joint ${ }^{88}$ adjudication or that invalidity may not be raised in any such actions, ${ }^{89}$ which usually leads to split adjudication. ${ }^{90}$ The above advantages apply mutatis mutandis even though split adjudication is sometimes not up to the free will of the plaintiff acting as the infringer but is decided for him/her.

1.30 Factor 8 is whether threatened infringement actions are allowed. Allowing such actions is an advantage for the plaintiff acting as the rightholder since he/she by being the first mover may choose the forum, which, in turn limits his/her risks and since he/she may save time and costs given that a possible infringement is addressed even before it starts. ${ }^{91}$

1.31 Factor 9 is whether non-infringement actions are allowed. Allowing noninfringement actions is an advantage for the plaintiff acting as the infringer since he/she by being the first mover may choose the forum, which, in turn, limits his/her risks.

1.32 In sum, the advantages for the plaintiff can be illustrated as in Table 1.2 below:

\section{Table 1.2 Jurisdictional advantages}

\begin{tabular}{|c|c|c|c|}
\hline Factor & Nature & Impact & Advantages for the plaintiff \\
\hline 1 & General & $\begin{array}{l}\text { Whether more } \\
\text { forum rules are } \\
\text { available }\end{array}$ & $\begin{array}{l}\text { More forum rules is an advantage for the plaintiff since } \\
\text { they provide for a discretion where to sue }\end{array}$ \\
\hline 2 & $\begin{array}{l}\text { General/ } \\
\text { Specific }\end{array}$ & $\begin{array}{l}\text { Whether one } \\
\text { forum rule } \\
\text { allows for more } \\
\text { available fora }\end{array}$ & $\begin{array}{l}\text { More available fora is an advantage for the plaintiff } \\
\text { since they provide for a discretion where to sue unless } \\
\text { only one party benefits in which event it may only be } \\
\text { an advantage for the plaintiff acting as the rightholder } \\
\text { or as the infringer }\end{array}$ \\
\hline 3 & General & $\begin{array}{l}\text { Whether a } \\
\text { plaintiff's own } \\
\text { domicile is } \\
\text { available }\end{array}$ & $\begin{array}{l}\text { - A plaintiff's own domicile is an advantage for the } \\
\text { plaintiff since it saves him/her time and costs for } \\
\text { travelling, external counsels and translation and since it } \\
\text { makes him/her feel more confident given that the case } \\
\text { is conducted on the basis of home procedural laws }\end{array}$ \\
\hline 4 & General & $\begin{array}{l}\text { Whether the } \\
\text { extent of } \\
\text { jurisdiction is } \\
\text { unlimited or } \\
\text { limited }\end{array}$ & $\begin{array}{l}\text { - A discretion between unlimited full and limited forum } \\
\text { jurisdiction is an advantage for the plaintiff }\end{array}$ \\
\hline
\end{tabular}

86 Arts 4, 7(2) and 7(5) Brussels I Regulation and art. 63(e) ROP.

87 Art. 24(4) BR.

88 Art. 33(4) AUPC.

89 Arts 99(2) EUTMR and 84(4) CDR.

90 Arts 56 EUTMR and 52 CDR concerning the registered CD.

91 Report on the Convention on the Association of the Kingdom of Denmark, Ireland and the United Kingdom of Great Britain and Northern Ireland to the Convention on Jurisdiction and the Enforcement of Judgments in Civil and Commercial matters and the Protocol on its Interpretation by the Court of Justice by Professor Dr. Peter Schlosser (Sclosser report) at 134. 


\begin{tabular}{|c|c|c|c|}
\hline Factor & Nature & Impact & Advantages for the plaintiff \\
\hline 5 & Specific & $\begin{array}{l}\text { Whether change } \\
\text { of forum } \\
\text { principles and } \\
\text { rules apply }\end{array}$ & $\begin{array}{l}\text { Change of forum principles and rules are an advantage } \\
\text { for the plaintiff acting as the infringer since they allow } \\
\text { the action to be prolonged }\end{array}$ \\
\hline 6 & Specific & $\begin{array}{l}\text { Whether } \\
\text { invalidity in } \\
\text { infringement } \\
\text { actions leads to } \\
\text { joint or split } \\
\text { adjudication }\end{array}$ & $\begin{array}{l}\text { - Joint adjudication is an advantage for the plaintiff } \\
\text { acting as the rightholder since the action is speeded up } \\
\text { - Split adjudication is an advantage for the plaintiff } \\
\text { acting as the infringer since the action is prolonged }\end{array}$ \\
\hline 7 & Specific & $\begin{array}{c}\text { Whether } \\
\text { invalidity in } \\
\text { non-infringement } \\
\text { actions leads to } \\
\text { joint or split } \\
\text { adjudication } \\
\end{array}$ & $\begin{array}{l}\text { - Joint adjudication is an advantage for the plaintiff } \\
\text { acting as the rightholder since the action is speeded up } \\
\text { - Split adjudication is an advantage for the plaintiff } \\
\text { acting as the infringer since the action is prolonged }\end{array}$ \\
\hline 8 & Specific & $\begin{array}{l}\text { Whether } \\
\text { threatened } \\
\text { infringement } \\
\text { actions are } \\
\text { permitted }\end{array}$ & $\begin{array}{l}\text { - Threatened infringement actions is an advantage for } \\
\text { the plaintiff acting as the rightholder since he/she is the } \\
\text { first mover and since an infringement can be addressed } \\
\text { before it starts }\end{array}$ \\
\hline 9 & Specific & $\begin{array}{l}\text { Whether } \\
\text { non-infringement } \\
\text { actions are } \\
\text { permitted }\end{array}$ & $\begin{array}{l}\text { - Non-infringement actions is an advantage for the } \\
\text { plaintiff acting as the infringer since he/she is the first } \\
\text { mover }\end{array}$ \\
\hline
\end{tabular}

5. Limits

The limits of the study can be divided into overall four groups i.e. the jurisdiction limits (section a), the applicable law limits (section b), the substantive IP law limits (section c) and the recognition and enforcement limits (section d).

\section{(a) Jurisdiction limits}

The jurisdiction limits, which relate to the first stage of the infringement procedures, count seven sublimits.

Limit 1 relates to the IP rights. Following this limit, IP rights other than the ones mentioned in section 3(a) are not addressed. Thus, copyrights, moral rights, utility model rights and from a broader perspective trade secrets, personality rights, goodwill and the rights protecting the names of agricultural products and foodstuffs, namely the protected designation of origin rights (PDO), the protected geographical indication right (PGI) and the speciality guaranteed right (SPG) are disregarded. The reason for disregarding the former six (copyrights, moral rights, utility model rights, trade secrets, personality rights and goodwill) is that they are not found in European unitary versions whereas the reason for disregarding the latter three (PDO, PGI and $\mathrm{SPG}$ ) is, despite being found in European unitary versions that they are subject to the forum rules in the BR and therefore do not fit in with the study. 
As an exception the above IP rights are addressed if they contribute to the overall purpose of the study. Any such purpose is met for copyrights and personality rights due to the CJEU's judgments in, inter alia, Pinckney, ${ }^{92} \mathrm{Hi}$ Hotel, ${ }^{93}$ Shervill ${ }^{94}$ and $e$-Date ${ }^{95}$ which all concern interpretations of the forum delicti rule being a key element of the present study cf. section 3(c) and so those judgments are referred to, inter alia, in Chapter 9.

1.36 Limit 2 relates to the litigations. Following this limit, actions other than the ones mentioned in section 3(b) are not addressed. Thus, administrative actions on opposition and validity as well as court actions, which do not involve an element of infringement such as validity actions or non-infringement actions testing a 'freedom to operate' and finally actions for preliminary injunctions and possible confirmatory actions are disregarded. As an exception the above actions are addressed if they contribute to the overall purpose of the study. Any such purpose is met partly for the CPV given that invalidity of any such right must be brought with the $\mathrm{CPVO}^{96}$ and partly for the EUTM and the CD given that invalidity of any such rights cannot be raised in a non-infringement action meaning that the EUIPO comes into play. ${ }^{97}$

1.37 Limit 3 relates to the jurisdiction rules. Following this limit, forum rules other than the ones mentioned in section 3(c) are not addressed. Thus, the explicit forum agreements' rule (allowing the parties to agree on jurisdiction), the implicit forum agreements' rule (allowing the defendant to establish jurisdiction by appearing before a court out of his/her own motion) and the annexed jurisdiction rule (allowing IP infringement actions to be brought where the criminal action is pending) are disregarded. The reason for disregarding the forum agreements' rules is that any such agreements would make the study redundant provided that the parties keep themselves within the limits of the rules ${ }^{98}$ since otherwise the agreements would be void and that the explicit forum agreement rule would require a contractual obligation between the parties e.g. by way of a forum law clause in a license agreement, which is not covered by the scope of the study cf. section 3(b). The reason for

92 Case C-170/12, Peter Pinckney.

93 Case C-387/12, Hi Hotel.

94 Case C-68/93, Fiona Shevill.

95 Joined cases C-509/09, e-Date Advertising GmbH $v X$ and case C-161/10, Olivier Martinez and Robert Martinez $v$ MGN Ltd.

96 Chapter 11, section C.3.

97 Ibid., sections C.2(a) and C.2(b).

98 One limit is that a forum agreement cannot waive art. 24(4) Brussels I Regulation cf. arts 25 and 26 Brussels I Regulation and another limit is that a forum agreement cannot waive the exclusive jurisdiction of EUTM or CD courts cf. art. 97(4) cf. 94(2)(b) EUTMR and arts 82(4) cf. 79(3)(b) CDR. 
disregarding the annexed jurisdiction rule is that any such rule is not compatible with a plaintiff's approach cf. section 4 since in criminal actions the 'plaintiff' is always the rightholder and never the infringer and that the rule is rarely used in practical life since the rightholder usually fears that the infringer may not be able to pay both compensation and a fine and so focus lies with the former.

Limit 4 relates to the nature of the invalidity claim. Following this limit, the ways invalidity are raised in infringement or non-infringement proceedings i.e. by way of a claim, counterclaim or possibly by way of a defence as well as the grounds for claiming invalidity ${ }^{99}$ is not addressed. Only the option of claiming/not claiming invalidity and the body competent to hear invalidity are addressed.

Limit 5 relates to the Member States' and third states' own international 1.39 forum rules. Following this limit, the numbers and natures of the Member States' own international forum rules, ${ }^{100}$ which allow e.g. a US defendant to be sued in a Member State as well as the numbers and natures of third states' own international forum rules, which allow e.g. a US defendant to be sued in his/her home state are not addressed including the conditions under which they apply. The rules are merely referred to as such. The reason is that they vary widely. ${ }^{101}$

Limit 6 relates to the competence of the UPC. Following this limit, the competence of the UPC for European patents, which the proprietors can escape from for a limited period of time if they continue to litigate before national courts, ${ }^{102}$ is not addressed. The reason is that litigating a European patent before the UPC expresses a 'third path' since invalidity of any such patent designating more than Contracting Member States e.g. the entire EU is subject to a combination of rules namely the rules in the AUPC for Contracting (EU) Member States and the rules in the BR for non-Contracting (EU) Member States ${ }^{103}$ and that accordingly any such 'third path' does not fit in with the study. The UPC's competence for European patents is, however, addressed if it contributes to the overall purpose of the study. Any such purpose

99 Section 3(b) for examples.

100 Art. 6 Brussels I Regulation.

101 Kono, supra note 2.

102 Art. 83(1) AUPC.

103 Non-paper from the Commission Services regarding the Compatibility of the Draft Agreement on the Unified Patent Court with the Union Aquis (14191/11 LIMITE PI 114 COUR 50) of 20 September 2011, pp. 3 and 7. 
is met, inter alia, in order to interpret the extent of jurisdiction under the AUPC and the forum delicti rule under the AUPC cf. Chapters 5 and 9.

1.41 Limit 7 relates to the stay of procedure rules. Following this limit, the rules on same actions (lis pendens) and the rules on related actions including the impact of such rules in IP litigation - e.g. by way of the so-called 'torpedos' where non-infringement actions are brought against the rightholder at slow moving courts in order to forestall an action on the merits - are not addressed unless they contribute to the overall purpose of the study. Any such purpose is met, inter alia, in regards to the central division rule in the AUPC cf. Chapter 10 and in regards to the forum delicti rules in the EUTMR and CDR cf. Chapter 9.

\section{(b) Applicable law limits}

1.42 Applicable law relates to the second stage of the infringement procedures. Such issues being limit 8 are not addressed unless they contribute to the overall purpose of the study. Any such purpose is met for the rules in the Rome II Regulation given that the applicable law rules must be interpreted in line with the forum law rules in the Brussels I Regulation ${ }^{104}$ and so the Rome II Regulation rules are referred to, inter alia, in Chapter 9.

\section{(c) Substantive IP law limits}

1.43 Substantive IP law relates to the third stage of the infringement procedures. Such issues being limit 9 are not addressed unless they contribute to the overall purpose of the study. Any such purpose is met for the WIPO Joint Recommendation ${ }^{105}$ and the CJEU's judgment in L'Oréal 106 since they both address when an infringer is subject to the IP laws of a forum state with a potential IP infringement to follow thus illustrating the interconnection with the jurisdiction rules and so they are referred to, inter alia, in Chapter 9.

\section{(d) Recognition and enforcement limits}

1.44 Recognition and enforcement relates to the final stage of the infringement procedures. Such issues being limit 10 are not addressed unless they contribute to the overall purpose of the study. Any such purpose is met in order to

104 Recital (7) Rome II Regulation.

105 WIPO Joint Recommendation Concerning Provisions on the Protection of Marks, and other Industrial Property Rights in Signs, on the Internet. The Recommendation was adopted by the Assembly of the Paris Union for the Protection of Industrial Property and the General Assembly of the World Intellectual Property Organization (WIPO) at the 36th Series of Meetings of the Assemblies of the Member States of WIPO September 24-October 3, 2001.

106 Case C-324/09, L'Oréal SA and Others v eBay International AG and others. 
illustrate possible impacts of CJEU judgments, inter alia, Wintersteiger. ${ }^{107}$ For the purpose of the present limit the term 'enforcement' addresses the meaning within Chapter III, section 2 Brussels I Regulation, which is not to be confused with the term 'effective enforcement' addressed in Chapter 4 section B. In sum, the limits of the study can be illustrated as in Table 1.3 below:

\section{Table 1.3 Limits of the study}

\begin{tabular}{|c|c|c|}
\hline \multirow{7}{*}{ Jurisdiction limits } & Limit 1 & $\begin{array}{l}\text { - Copyrights } \\
\text { - Moral rights } \\
\text { - Utility model rights } \\
\text { - Trade secrets } \\
\text { - Personality rights } \\
\text { - Goodwill } \\
\text { - Protected designation of origin rights (PDO) } \\
\text { - Protected geographical indication rights (PGI) } \\
\text { - Speciality guaranteed rights (SPG) }\end{array}$ \\
\hline & Limit 2 & $\begin{array}{l}\text { - Actions at administrative authority level } \\
\text { o Actions on opposition } \\
\text { o Actions on validity } \\
\text { - Actions at court level } \\
\text { o Actions not involving an element of infringement } \\
\text { Actions on validity } \\
\text { Actions testing a 'freedom to operate' } \\
\text { o Actions for preliminary injunction and possible confirmatory } \\
\text { actions }\end{array}$ \\
\hline & Limit 3 & $\begin{array}{l}\text { - The explicit forum agreements' rule } \\
\text { - The implicit forum agreements' rule } \\
\text { - The annexed jurisdiction rule }\end{array}$ \\
\hline & Limit 4 & $\begin{array}{l}\text { - Nature of an invalidity claim } \\
\text { - Nature of an invalidity counterclaim } \\
\text { - Nature of an invalidity defence }\end{array}$ \\
\hline & Limit 5 & $\begin{array}{l}\text { - Member States' own international forum rules } \\
\text { - Third states' own international forum rules }\end{array}$ \\
\hline & Limit 6 & - UPC's competence for European patents \\
\hline & Limit 7 & $\begin{array}{l}\text { - Stay of procedure rules on same actions (lis pendens) } \\
\text { - Stay of procedure rules on related actions }\end{array}$ \\
\hline Applicable law limits & Limit 8 & \multirow{3}{*}{ Not addressed } \\
\hline Substantive law limits & Limit 9 & \\
\hline $\begin{array}{l}\text { Recognition and } \\
\text { enforcement limits }\end{array}$ & Limit 10 & \\
\hline
\end{tabular}

\section{B. STRUCTURE}

The book is divided overall into four parts, which are subdivided into $12 \mathbf{1 . 4 5}$ chapters as outlined below.

Part I is titled 'Introduction' and encompasses the present Chapter 1. The $\mathbf{1 . 4 6}$ chapter sets the limits for the study. 
1.47 Part II is titled 'Number of jurisdiction rules' and encompasses two chapters. In Chapter 2 the jurisdiction framework is examined (general level) and from the findings in that chapter the jurisdiction rules are outlined in Chapter 3 (specific level). Accordingly, Chapters 2-3 will provide the answer to the number of international jurisdiction rules available to the plaintiff.

1.48 Part III is named 'Nature of jurisdiction rules' and encompasses eight chapters. In Chapter 4 the principles on which the jurisdiction rules are based are outlined (general level). Then, the jurisdiction rules as such are addressed (specific level). Thus, in Chapter 5 the defendant's domicile rule is examined; in Chapter 6 the establishment rule is examined; in Chapter 7 the plaintiff's domicile rule is examined; in Chapter 8 the multiple defendants' rule is examined; in Chapter 9 the forum delicti rule is examined; in Chapter 10 the central division rule is examined and finally in Chapter 11 the exclusive jurisdiction rule is examined. ${ }^{108}$ Accordingly, Chapters $4-11$ will provide the answer to the nature of the international jurisdiction rules available to the plaintiff.

1.49 Part IV is titled 'Conclusion' and encompasses one chapter. In Chapter 12 a conclusion is drawn. Accordingly, Chapter 12 will provide the answer to the study.

108 The reason for addressing the forum rules in the above order which differs from the order in the BR where the defendant's domicile is addressed first (art. 4 Brussels I Regulation), forum delicti second (art. 7.2 Brussels I Regulation) and establishment third (art. 7.5 Brussels I Regulation) is twofold, i.e. that the defendant's domicile and establishment rules are interrelated given that the latter is known as the 'small' defendant's domicile rule cf. Chapter 6 and that Chapters 5-9 reflect the structure from arts 97 EUTMR, 82 CDR and 101 CPVR. The exclusive jurisdiction rule is addressed primarily in Chapter 11 which, however, does not exclude that the effect of raising invalidity under the respective forum rules addressed in Chapters 5-10 is briefly outlined. A general reference is made in those chapters to Chapter 11 . 